\title{
Evaluating Performance of Sixteen Upland Rice Genotypes under Field Conditions for Further Breeding Process
}

\author{
Tajamul Hussain ${ }^{1}$, Jakarat Anothai ${ }^{1}$, Charassri Nualsri ${ }^{1} \&$ Watcharin Soonsuwon ${ }^{1}$ \\ ${ }^{1}$ Department of Plant Science, Faculty of Natural Resources, Prince of Songkla University, Hat Yai, Thailand \\ Correspondence: Watcharin Soonsuwon, Department of Plant Science, Faculty of Natural Resources, Prince of \\ Songkla University, Hat Yai, 90112, Thailand. Tel: 66-807-047-329. E-mail: watcharin.s@psu.ac.th
}

Received: December 25, 2017

Accepted: January 25, $2018 \quad$ Online Published: February 15, 2018

doi:10.5539/jas.v10n3p144

URL: https://doi.org/10.5539/jas.v10n3p144

\begin{abstract}
Rice is second most consumed cereal after wheat and it is considered as staple food in Thailand and most of the ASEAN countries. Analyzing yield performance of upland rice genotypes under field conditions is a key step in rice crop breeding program for improved rice production and ensuring food security. The objective of this research was to conduct a yield trial to assess performance of sixteen Thai upland rice genotypes under field conditions for further breeding process. Data from field trial that was conducted in 2016 in field research area of Faculty of Natural Resources, Prince of Songkla University, Hat Yai, Thailand was used in this assessment. Randomized complete block design (RCBD) with three replications was used to layout the experiment in field. Soil was analyzed upto $50 \mathrm{~cm}$ soil depth for its fertility and nutrient status to check the fertilizer requirements before planting. Soil moisture contents were recorded using PR2/6 probe. Observed moisture contents indicated that there was $60-70 \%$ water available to all genotypes based on filed capacity (FC). Results indicated that genotypes, Hawm Mali Doi, Jao Khao Pichit, Jao Daeng, Sahm Deuan and Ma-led-nai-fai were shorter in plant height while genotypes Ma-led-nai-fai, Goo Meung Lung, Jao Daeng, Dawk Pa-yawm and Hawm Jet Ban had higher number of tillers $\mathrm{m}^{-2}$. Genotypes Ma-led-nai-fai, Goo Meung Lung, Jao Daeng, Dawk Pa-yawm and Hawm Jet Ban had higher number of panicles $\mathrm{m}^{-2}$. Genotypes Jao Daeng, Ma-led-nai-fai, Sahm Deuan, Hawm Mali Doi and Jao Khao Pichit were early flowering and maturity considering as early maturity genotypes. Genotypes Goo Meung Lung, Hawm Mali Doi, Jao Khao Pichit, Jao Daeng and Mai Tahk had higher 1000 GW while genotypes Dawk Kham, Dawk Kha, Hawm Jet Ban, Dawk Pa-yawm and Bow Leb Nahag were superior in grain yield response. Performance of genotypes indicated that these genotypes can be used for further breeding process for acquiring desired traits.
\end{abstract}

Keywords: upland rice, yield assessment, soil moisture contents

\section{Introduction}

Rice (Oryza sativa L.) is commonly used cereal as a staple food after wheat for a significant part of human population. Upland rice contributes around 4\% in total rice production in the world. Upland rice contributes about $10 \%$ of the total rice area in Thailand which is grown in northern and southern parts of country (Nokkoul et al., 2011). The upland rice system prevails in dry lands without irrigation as well as puddling. These environments mostly suffer from various abiotic stresses accompanied with improbable rainfalls. In upland rice areas, environmental conditions are erratic ranging from humid to sub-humid. Soil and topography of these locations are moderately fertile to remarkably infertile and smoothly to sharp sloppy respectively. Rice farming in these rain fed areas is risk-prone.

Global warming increases the drought occurrence (Farooq et al., 2009) which results in global water scarcity. Upland areas mostly suffer from sporadic occasions of abiotic stresses like droughts and floods thus lowering the production efficiency of these areas. In future prediction of climate change, it is estimated that the water shortfall is going to be more severe (Wassmann et al., 2009), and Bates et al. (2008) stated that the concentration and frequency of drought will be increased. Drought occurrence obstructs the rice performance. Rice growth period in rain-fed areas are prone to dry spells occurring anytime which leads to drought of different concentration yet rice is considered highly sensitive when drought occurring at reproductive stages (O'Toole, 1982; Venuprasad et al., 2007) as floral development is badly effected under water stress. Most of the physiological and biochemical processes are slowed down in drought stress conditions. Upland rice without puddling is cultivated in rainy 
season in southern Thailand. Rainy season lasts from May to October and the upland rice planted in months of May to July is at reproductive stage at the end of rainy season. Due to less rainfall and occurrence of drought in the end of rainy season critically affects the rice yield. Heat is another factor during the growth period which increase the crop damage along with drought. Upland rice is potential source of genetic traits for rice breeding program and its performance is declining every year due to abiotic stresses. Therefore it becomes important to screen the upland rice genotypes having capability to tolerate drought and heat stresses especially at reproductive stages. Number of these abiotic stresses including drought and heat need to combat by screening and developing improved genotypes. Breeding upland rice for drought tolerance and heat to avoid the abiotic stresses is one of the important factor to increase the efficiency of rice production. Selection and development of the drought tolerant upland rice genotypes is important in southern Thailand as the local genotypes has the potential of higher productivity in stress conditions. Keeping in view the problems associated with upland rice production there was a need to assess the performance of upland rice genotypes for different agronomic trains under field conditions to use the suitable genotypes for further breeding process. Therefore, we selected sixteen Thai upland rice genotypes commonly grown in southern of Thailand for evaluating their response for agronomic traits including their growth duration and different yield attributes.

\section{Material and Methods}

\subsection{Soil Analysis}

Soil analysis involved collection of input data on soil characteristics upto $0-50 \mathrm{~cm}$ on soil class, texture, field capacity, electrical conductivity, organic carbon, organic matter, soil texture, $\mathrm{pH}$ of soil in water, cation exchange capacity, organic carbon, total nitrogen, phosphorus, potassium, calcium sodium and zinc, which was performed at Central laboratory, Faculty of Natural Resources, Prince of Songkla University, Hat Yai, Thailand. Physical and chemical properties of soil are detailed in Table 1.

Table 1. Soil physical and chemical properties upto $50 \mathrm{~cm}$ soil depth

\begin{tabular}{|c|c|c|c|c|c|c|}
\hline \multirow{4}{*}{ Soil Properties } & \multirow{4}{*}{ Units } & \multicolumn{3}{|c|}{ Values at Soil Layer Depths $(\mathrm{cm})$} & \multirow{4}{*}{ Method/Equipment } & \multirow{4}{*}{ References/Model } \\
\hline & & $0-15$ & $15-30$ & $30-50$ & & \\
\hline & & Sandy & Sandy Clay & Sandy & & \\
\hline & & Loam & Loam & Clay & & \\
\hline \multirow{3}{*}{ Texture } & $\%$ Sand & 70.56 & 63.75 & 55.52 & \multirow{3}{*}{ Hydrometer method } & \multirow{3}{*}{$\begin{array}{l}\text { Bouyoucos,1936; } \\
\text { Day, } 1965\end{array}$} \\
\hline & $\%$ Silt & 11.86 & 10.48 & 8.28 & & \\
\hline & $\%$ Clay & 17.58 & 25.77 & 36.20 & & \\
\hline Field capacity & $\%$ & 33.60 & 38.52 & 46.42 & Gravimetric method & Cassel \& Nielsen, 1986 \\
\hline Electrical conductivity & $\mu \mathrm{S} \mathrm{cm}^{-1}$ & 43.4 & 45.6 & 58.6 & EC meter & $\begin{array}{l}\text { Seven Easy EC Meter } \\
\text { (Mettler Toledo) }\end{array}$ \\
\hline Soil $\mathrm{pH}$ & Slightly Acidic & 4.92 & 5.22 & 5.13 & $\mathrm{pH}$ meter & $\begin{array}{l}\text { Seven Easy } \\
\text { (Mettler Toledo) } 8603\end{array}$ \\
\hline Organic carbon & $\%$ & 0.67 & 0.48 & 0.42 & \multirow{2}{*}{ Walkley \& Black's method } & \multirow{2}{*}{ Walkley \& Black, 1934} \\
\hline Organic matter & $\%$ & 1.15 & 0.82 & 0.72 & & \\
\hline Cation exchange capacity & meq/100 g soil & 3.59 & 4.42 & 5.27 & $\begin{array}{l}\text { Exchangeable cation } \\
\text { extraction method }\end{array}$ & Ross, 2009 \\
\hline Total N & $\%$ & 0.07 & 0.06 & 0.05 & Kjeldahl method & Kjeldahl,1883 \\
\hline Available P & $\%$ & 52.21 & 27.24 & 15.53 & Bray no. II & Bray, 1945 \\
\hline Potassium & $\mathrm{mg} \mathrm{kg}^{-1}$ & 101.30 & 100.74 & 100.76 & $\begin{array}{l}\text { Exchangeable cation } \\
\text { extraction }\end{array}$ & $\begin{array}{l}\text { Thomas, 1982; } \\
\text { Levinson, } 1969\end{array}$ \\
\hline Calcium & $\mathrm{mg} \mathrm{kg}^{-1}$ & 380.15 & 569.14 & 606.80 & $\begin{array}{l}\text { Exchangeable cation } \\
\text { extraction }\end{array}$ & $\begin{array}{l}\text { Thomas, 1982; } \\
\text { Levinson, } 1969\end{array}$ \\
\hline Sodium & $\mathrm{mg} \mathrm{kg}^{-1}$ & 7.03 & 9.94 & 12.70 & DTPA extraction method & Lindsay \& Norvell, 1978 \\
\hline Zinc & $\mathrm{mg} \mathrm{kg}^{-1}$ & 3.31 & 2.37 & 1.09 & DTPA extraction method & Lindsay \& Norvell, 1978 \\
\hline
\end{tabular}

\subsection{Experimental Details}

Sixteen Thai upland rice genotypes including, Jao Khao Pichit, Jao Daeng, Sahm Deuan, Dawk Kham, Dawk Kha Hawm Jet Ban, Khao Sai, Khao Ruang, Nual Hawm, Ma-led-nai-fai, Dawk Pa-yawm, Goo Meung Lung, Hua Bon, Bow Leb Nahag and Mai Tahk were used in this study. Experiment for yield assessment under field conditions was conducted in field research area of Faculty of Natural Resources, Prince of Songkla University, 
Hat Yai, Thailand, using RCBD with three replications. Plant population was maintained at 13 plants $\mathrm{m}^{-2}$ by keeping $30 \mathrm{~cm}$ row to row and $25 \mathrm{~cm}$ plant to plant distance and sowing was performed by direct seeding method. Optimum amount of fertilizer at rate of $75 \mathrm{~kg} \mathrm{~N}, 45 \mathrm{~kg} \mathrm{P}$ and $45 \mathrm{~kg} \mathrm{~K}^{+} \mathrm{ha}^{-1}$ was applied in three splits. Irrigation was applied using sprinklers when plants were observed under wilting and rainfall was also received by plants during growing season. Soil moisture contents were recorded by using PR2/6 probe (Delta-T Devices) upto $100 \mathrm{~cm}$ at $0-10,10-20,20-30,30-40,40-60$ and $60-100 \mathrm{~cm}$ soil depths. Three PR2/6 probes were installed in each replication of experiment and moisture contents were recorded on weekly basis.

\subsection{Data Collection and Analysis}

Data collection and calculation of yield parameters was done by destructive method (Soler et al., 2013) and large area sample plus subsample approach, as a way to minimize work load and to minimize sample variability. The principle proposed includes taking a large sample (about $1 \mathrm{~m}^{2}$ land area) for land-area dependent biomass to reduce the coefficient of variation (CV), and then taking a small subsample (1 to 3 plants) for plant internal traits having low CV's. Three plant were selected for subsample from which plants parts were separated into leaves, stems and panicles. Samples were dried in oven at $70{ }^{\circ} \mathrm{C}$ for various durations depending upon the plant part until no change in weight was observed. Obtained data was analyzed $(P<0.05$ and $P<0.01)$ using statistical software R-2.14.0 to test the significance of results and mean comparison.

\section{Results and Discussion}

\subsection{Weather Conditions}

Data relating to daily maximum (Tmax.) and minimum (Tmin.) air temperature and average daily rainfall was obtained from Kho Hong agro-meteorology station located about five kilometres to experimental site. Mean Tmax., Tmin. and average daily rainfall during season were $42.0,24.8^{\circ} \mathrm{C}$ and $5.8 \mathrm{~mm}$ day ${ }^{-1}$ respectively (Figure 1). Primary atmospheric variables that impact on crop growth are solar radiation, air temperature, humidity, and precipitation. Optimum temperature required for rice growth ranged from $25^{\circ} \mathrm{C}$ to $35{ }^{\circ} \mathrm{C}$ (Yoshida, 1978) while temperature prevailed during the growth period was higher than optimum range which indicated that temperature had influence on crop growth and development. Less rainfall occurred during the growth period which caused a stress to all genotypes at different growth stages.

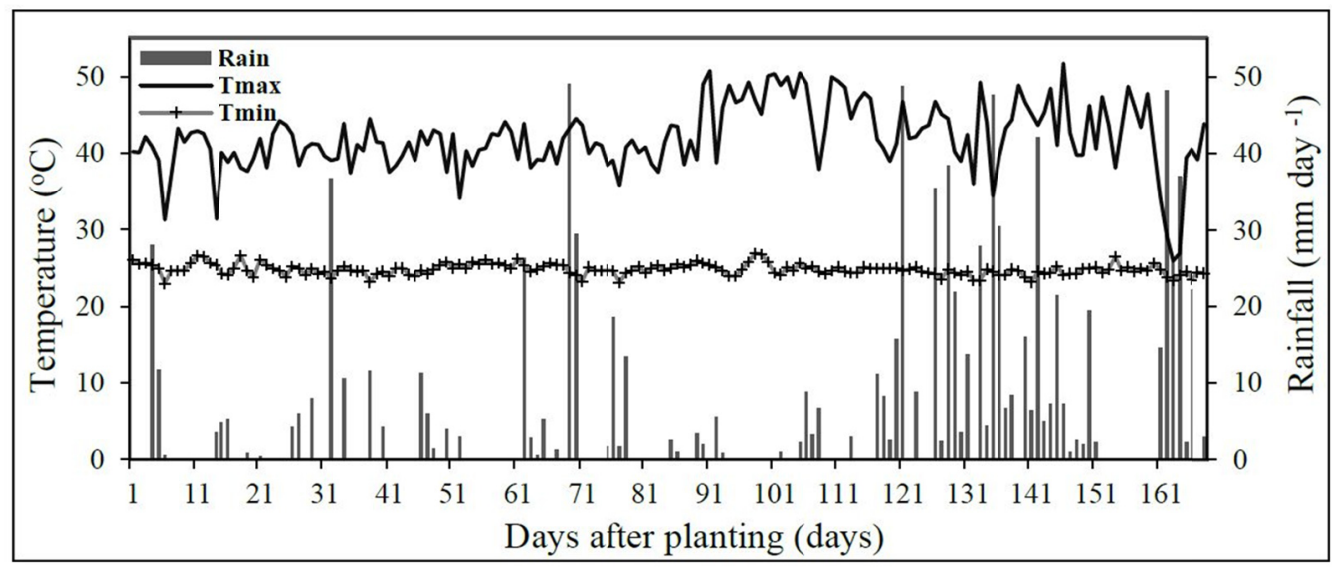

Figure 1. Mean daily maximum and minimum temperature and rainfall occurred during experiment

\subsection{Soil Moisture Contents}

Soil moisture contents recorded during the season were lower than the full crop requirement of $100 \% \mathrm{FC}$. Soil moisture contents ranged between 15.8 to $23.4 \%$ of $\mathrm{FC}$ for $0-10 \mathrm{~cm}$ (Figure 2 [a]), 16.0 to $23.3 \%$ of $\mathrm{FC}$ for $10-20$ $\mathrm{cm}$ (Figure 2 [b]), 18.3 to $24.8 \%$ of $\mathrm{FC}$ for $20-30 \mathrm{~cm}$ (Figure 2 [c]), 14.0 to $20.8 \%$ of $\mathrm{FC}$ for $30-40 \mathrm{~cm}$ (Figure 2 [d]), 20.7 to $27.9 \%$ of FC for $40-60 \mathrm{~cm}$ (Figure 2 [e]) and 34.1 to $41.7 \%$ of FC for $60-100 \mathrm{~cm}$ (Figure 2 [f]) respectively. Overall all genotypes had $70 \%$ water availability of full crop requirement which indicated that all genotypes had a moderate water stress during its growth especially near flowering period. Rainfall was also less during the flowering period of most of genotypes (Figure 1). In upper soil layers upto $30 \mathrm{~cm}, \mathrm{FC}$ was near to $70 \%$ and it was decreased to $60 \%$ under deeper soil layers upto $60 \mathrm{~cm}$ while it was increased to $80 \%$ under 60 $100 \mathrm{~cm}$ soil layer (Figure 2). Although rice have deeper root length but its ability to extract water from deep soil 
layers is relatively low which makes rice more vulnerable to water stress. Kondo et al. (1999) stated that root pattern of rice varies from other crops. Turner et al. (2001) and Subbarao et al. (1995) described that root characteristics like length, Density, depth and biomass significantly contribute towards water economy. Deeper and thicker roots efficiently extracted water from deeper layers (Kavar et al., 2008). Rainfall occurrence and moisture contents in different soil layers indicated a high variation in soil water availability to plants and it showed that all genotypes had a moderate stress during the growth.
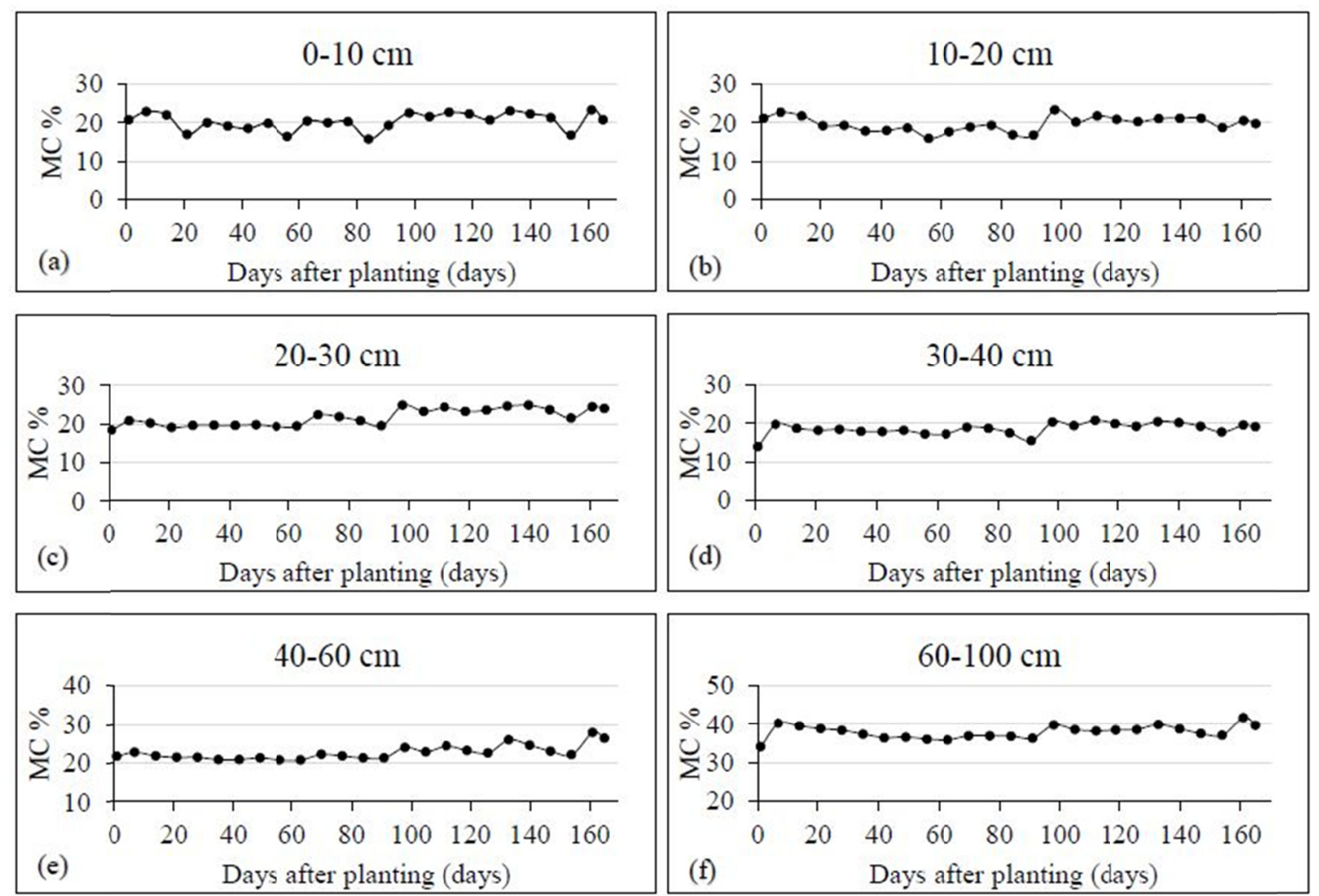

Figure 2. Soil moisture contents at each soil depth upto $100 \mathrm{~cm}$

\subsection{Genotypic Performance}

Results from analysis of variance indicated that there was a highly significant difference for plant height, number of tillers and panicles, days to flowering and maturity and one thousand grain weight and a significant difference for grain yield and biomass between all genotypes (Table 2). In comparison of means of agronomic traits of upland rice genotypes (Table 3), mean values ranged between 102 to 140 days and 120 to 161 days for days to flowering and maturity respectively. Mean values ranged between 98 to $181 \mathrm{~cm}, 116$ to 266 tillers and 106 to 191 panicles for PH, number of tillers and panicles respectively. For GY, $1000 \mathrm{GW}$ and biomass, mean values ranged from 1608.30 to $3994.70 \mathrm{~kg} \mathrm{ha}^{-1}, 24$ to $26.67 \mathrm{~g}$ and 3435.70 to $6968.70 \mathrm{~kg} \mathrm{ha}^{-1}$ respectively. Genotypes, Hawm Mali Doi, Jao Khao Pichit, Jao Daeng, Sahm Deuan and Ma-led-nai-fai were shorter in plant height while genotypes Ma-led-nai-fai, Goo Meung Lung, Jao Daeng, Dawk Pa-yawm and Hawm Jet Ban had higher number of tillers $\mathrm{m}^{-2}$. Dwarfness is required in rice crop breeding to avoid lodging losses. Shorter genotypes could be used for acquiring traits for shorter plant height in rice breeding. Genotypes Ma-led-nai-fai, Goo Meung Lung, Jao Daeng, Dawk Pa-yawm and Hawm Jet Ban had higher number of panicles $\mathrm{m}^{-2}$. Genotypes Jao Daeng, Ma-led-nai-fai, Sahm Deuan, Hawm Mali Doi and Jao Khao Pichit were early flowering and maturity considering as early maturity genotypes while genotypes Goo Meung Lung, Nual Hawm, Mai Tahk, Khao Ruang and Hua Bon were late flowering and maturity considering as late maturity genotypes. Genotypes Goo Meung Lung, Hawm Mali Doi, Jao Khao Pichit, Jao Daeng and Mai Tahk had higher 1000 GW while genotypes Hawm Jet Ban, Dawk Kham, Dawk Kha, Dawk Pa-yawm and Bow Leb Nahag were superior in grain yield response. Genotypes Mai Tahk, Goo Meung Lung, Dawk Kham, Hawm Jet Ban and Bow Leb Nahag produced maximum biomass (Table 3). Different 
agronomic parameters including days to flowing and maturity, number of tillers and panicles, $1000 \mathrm{GW}$ and GY have been focused to be accounting for screening genotypes in rice breeding (Yang et al., 2001; Venuprasad et al., 2008 \& Wang et al., 2010). Results showed that different genotypes could be considered for acquiring required traits in rice crop breeding program. For example early maturity genotypes should be considered for early maturing to escape drought stress which can be benefited in rice breeding for drought.

Table 2. Mean square of analysis of variance of agronomic traits of sixteen upland rice genotypes

\begin{tabular}{llllllllll}
\hline SOV & df & PH & NT & NP & DF & DM & GY & 1000 GW & Biomass \\
\hline Replication & 2 & 118.69 & 4575.15 & 6108.08 & 17.31 & 14.14 & 3903198 & 1.52 & 4420490 \\
Treatment & 15 & $1063.20^{* *}$ & $4150.44^{* *}$ & $1840.35^{* *}$ & $543.25^{* *}$ & $554.26^{* *}$ & $1667649^{*}$ & $39.65^{* *}$ & $3785735^{*}$ \\
Error & 30 & 98.82 & 1040.17 & 986.95 & 28.24 & 13.39 & 795138 & 2.98 & 2205423 \\
\hline CV \% & & 7.18 & 21.77 & 23.31 & 4.35 & 2.55 & 31.23 & 6.02 & 29.69 \\
\hline
\end{tabular}

Note. $\mathrm{SOV}=$ Source of variation, $\mathrm{df}=$ degree of freedom, $\mathrm{PH}=$ Plant height, $\mathrm{NT}=$ Number of tillers, NP $=$ Number of panicles, DF = Days to flowering, DM = Days to maturity, GY = Grain yield, $1000 \mathrm{GW}=$ one thousand grain weight, ${ }^{* *}=$ Highly significant, ${ }^{*}$ Significant.

Table 3. Mean of agronomic traits of sixteen upland rice genotypes

\begin{tabular}{|c|c|c|c|c|c|c|c|c|}
\hline Genotype & $\begin{array}{l}\mathrm{PH} \\
(\mathrm{cm})\end{array}$ & $\begin{array}{l}\text { NT } \\
\text { (no. } \mathrm{m}^{-2} \text { ) }\end{array}$ & $\begin{array}{l}\mathrm{NP} \\
\left(\text { no. } \mathrm{m}^{-2}\right)\end{array}$ & $\begin{array}{l}\text { DF } \\
\text { (days) }\end{array}$ & $\begin{array}{l}\mathrm{DM} \\
\text { (days) }\end{array}$ & $\begin{array}{l}\text { GY } \\
\left(\mathrm{kg} \mathrm{ha}^{-1}\right)\end{array}$ & $\begin{array}{l}1000 \mathrm{GW} \\
(\mathrm{g})\end{array}$ & $\begin{array}{l}\text { Biomass } \\
\left(\mathrm{kg} \mathrm{ha}^{-1}\right)\end{array}$ \\
\hline Hawm Mali Doi & 118 & 148 & 135 & 105 & 124 & 1805.20 & 34.67 & 3559.20 \\
\hline Jao Khao Pichit & 129 & 143 & 131 & 105 & 127 & 1608.30 & 32.67 & 3569.50 \\
\hline Jao Daeng & 115 & 179 & 164 & 102 & 120 & 1977.60 & 32.00 & 3435.70 \\
\hline Sahm Deuan & 131 & 125 & 120 & 103 & 126 & 2156.30 & 27.00 & 3440.20 \\
\hline Dawk Kham & 146 & 125 & 115 & 128 & 152 & 3994.70 & 26.00 & 5486.80 \\
\hline Dawk Kha & 151 & 116 & 115 & 127 & 151 & 3671.90 & 27.00 & 5746.40 \\
\hline Hawm Jet Ban & 141 & 149 & 142 & 126 & 150 & 3490.20 & 28.33 & 5764.20 \\
\hline Khao Sai & 137 & 141 & 129 & 128 & 151 & 2879.40 & 26.33 & 4779.40 \\
\hline Khao Ruang & 155 & 122 & 112 & 131 & 152 & 3079.20 & 28.00 & 5710.00 \\
\hline Nual Hawm & 152 & 118 & 106 & 134 & 151 & 2563.10 & 28.67 & 4483.40 \\
\hline Ma-led-nai-fai & 98 & 266 & 191 & 103 & 124 & 1996.90 & 24.00 & 4812.40 \\
\hline Dawk Pa-yawm & 141 & 155 & 143 & 129 & 151 & 3514.90 & 25.33 & 5428.90 \\
\hline Goo Meung Lung & 181 & 183 & 179 & 140 & 161 & 3355.60 & 36.67 & 6656.70 \\
\hline Hua Bon & 139 & 127 & 116 & 131 & 150 & 2889.90 & 26.00 & 4429.10 \\
\hline Bow Leb Nahag & 134 & 147 & 141 & 130 & 151 & 3365.00 & 26.00 & 5750.50 \\
\hline Mai Tahk & 146 & 127 & 118 & 133 & 152 & 3339.40 & 31.00 & 6968.70 \\
\hline Mean & 138 & 148 & 135 & 122 & 143 & 2855.5 & 28.72 & 5001.30 \\
\hline LSD 0.05 & 16.57 & 53.78 & 52.38 & 8.86 & 6.10 & 1532.80 & 2.88 & 2476.40 \\
\hline LSD 0.01 & 22.32 & 72.41 & 70.54 & 11.93 & 8.21 & 2063.90 & 3.88 & 3334.50 \\
\hline
\end{tabular}

Note. $\mathrm{PH}=$ Plant height, $\mathrm{NT}=$ Number of tillers, $\mathrm{NP}=$ Number of panicles, $\mathrm{DF}=$ Days to flowering, $\mathrm{DM}=\mathrm{Days}$ to maturity, $\mathrm{GY}=$ Grain yield, $1000 \mathrm{GW}=$ one thousand grain weight, LSD = Least significant difference.

\section{Conclusion}

In conclusion, genotypes Ma-led-nai-fai, Goo Meung Lung, Jao Daeng, Dawk Pa-yawm and Hawm Jet Ban had higher number of panicles $\mathrm{m}^{-2}$, genotypes Goo Meung Lung, Hawm Mali Doi, Jao Khao Pichit, Jao Daeng and Mai Tahk had higher 1000 GW while genotypes Dawk Kham, Dawk Kha, Hawm Jet Ban, Dawk Pa-yawm and Bow Leb Nahag were superior in grain yield response. These genotypes can be considered as high yielding genotypes. Genotypes Jao Daeng, Ma-led-nai-fai, Sahm Deuan, Hawm Mali Doi and Jao Khao Pichit were early flowering and maturity considering as early maturity genotypes while genotypes Goo Meung Lung, Nual Hawm, Mai Tahk, Khao Ruang and Hua Bon were late flowering and maturity considering as late maturity genotypes. Early maturity genotypes can be further used for breeding for drought and heat escaping. Authors, suggest for 
further experimentation for all of these genotypes under diverse range of soil and weather conditions for improved evaluation.

\section{Acknowledgements}

Research was supported by the Higher Education Research Promotion and the Thailand's Education Hub for Southern Region of ASEAN Countries Project Office of the Higher Education Commission. The authors acknowledge Graduate School and Faculty of Natural Resources, Prince of Songkla University, Hat Yai Campus for financial support.

\section{References}

Bates, B. C., Kundzewicz, Z. W., Wu, S., \& Palutikof, J. P. (2008). Climate change and water: Technical Paper of the Intergovernmental Panel on Climate Change (pp. 95-96). IPCC Secretariat, Geneva.

Bouyoucos, G. J. (1936). Directions for making mechanical analysis of soils by the hydrometer method. Soil Science, 42(3), 225-230. https://doi.org/10.1097/00010694-193609000-00007

Bray, R. H., \& Kurtz, L. T. (1945). Determination of total, organic and available forms of phosphorus in soils. Soil Science, 59(1), 39-46. https://doi.org/10.1097/00010694-194501000-00006

Cassel, D. K., \& Nielsen, D. R. (1986). Field capacity and available water capacity. Methods of Soil Analysis (Part 1), Physical and Mineralogical Methods (pp. 901-926).

Day, P. R. (1965). Particle fractionation and particle-size analysis. Methods of Soil Analysis (Part 1), Physical and Mineralogical Properties, Including Statistics of Measurement and Sampling (pp. 545-567).

Farooq, M., Wahid, A., Lee, D. J., Ito, O., \& Siddique, K. H. (2009). Advances in drought resistance of rice. Critical Reviews in Plant Sciences, 28(4), 199-217. https://doi.org/10.1080/07352680902952173

Kavar, T., Maras, M., Kidrič, M., Šuštar-Vozlič, J., \& Meglič, V. (2008). Identification of genes involved in the response of leaves of Phaseolus vulgaris to drought stress, Molecular Breeding, 21(2), 159-172. https://doi.org/10.1007/s11032-007-9116-8

Kjeldahl, J. G. C. T. (1883). Neue methode zur bestimmung des stickstoffs in organischen Körpern. Fresenius Journal of Analytical Chemistry, 22(1), 366-382. https://doi.org/10.1007/BF01338151

Kondo, M., Murty, M. V. R., Aragones, D. V., Okada, K., Winn, T., \& Kwak, K. S. (1999). Characteristics of the root system and water uptake in upland rice. Genetic improvement of rice for water-limited environments (pp. 117-134).

Levinson, A. A. (1969). Analytical methods for atomic absorption spectrophotometry (pp. 1315-1316). The Perkin-Elmer Corporation, Norwalk, Connecticut, USA. https://doi.org/10.1016/0016-7037(69)90053-2

Lindsay, W. L., \& Norvel, W. A. (1978). Development of a DTPA soil test for zinc, iron, manganese, and copper. Soil Science Society of America Journal, 42(3), 421-428. https://doi.org/10.2136/sssaj1978.03615995004 200030009x

Nokkoul, R., Wijitparp, T., \& Pimsri, K. (2011). Effects of Drought Condition on Growth and Yield of Organic Upland Rice Seed. Proceeding of the 8th National Seeds Conference Hotel, Sunee, Grand \& Convention Centre, May 17-20, 2011 (pp. 49-58). Ubon Ratchathani Province, Thailand.

O'Toole, J. C. (1982). Adaptation of rice to drought prone environments. Drought Resistance in Crops with Emphasis on Rice (pp. 195-213). IRRI, Los Baños, Philippines.

Ross, D. (2009). Soil Cation Exchange Capacity. Recommended Soil Testing Procedures for the Northeastern United States (3rd ed., p. 493). North East Regional Publications.

Soler, C. M. T., Suleiman, A., Anothai, J., Flitcroft, I., \& Hoogenboom, G. (2013). Scheduling irrigation with a dynamic crop growth model and determining the relation between simulated drought stress and yield for peanut. Irrigation Science, 31(5), 889-901. https://doi.org/10.1007/s00271-012-0366-9

Subbarao, G. V., Johansen, C., Slinkard, A. E., Nageswara Rao, R. C., Saxena, N. P., Chauhan, Y. S., \& Lawn, R. J. (1995). Strategies and scope for improving drought resistance in grain legumes. Critical Reviews in Plant Sciences, 14(6), 469-523. https://doi.org/10.1080/07352689509701933

Thomas, G. W. (1982). Exchangeable Cations. Methods of soil analysis (Part 2), Chemical and microbiological properties (pp. 159-165). 
Turner, N. C., Wright, G. C., \& Siddique, K. H. M. (2001). Adaptation of grain legumes (pulses) to water-limited environments. Advances in Agronomy, 71, 193-231. https://doi.org/10.1016/S0065-2113(01) $71015-2$

Venuprasad R., Cruz, M. S., Aamte, M., Magbanua, R., Kumar, A., \& Atlin, G. N. (2008). Responses to two cycles of divergent selections for grain yield under drought stress in four rice breeding populations. Field Crops Research, 107(3), 232-244. https://doi.org/10.1016/j.fcr.2008.02.004

Venuprasad, R., Lafitte, H. R., \& Atlin, G. N. (2007). Response to direct selection for grain yield under drought stress in rice. Crop Science, 47(1), 285-293. https://doi.org/10.2135/cropsci2006.03.0181

Walkley, A., \& Black, I. A. (1934). An examination of Degtjareff method for determining soil organic matter, and proposed modification of the chromic acid titration method. Soil Science, 37(1), 29-38. https://doi.org/ 10.1097/00010694-193401000-00003

Wang, H. Z., Zhang, L. H., Jun, M. A., Li, X. Y., Yan, L. I., Zhang, R. P., \& Wang, R. Q. (2010). Effects of water stress on reactive oxygen species generation and protection system in rice during grain-filling stage. Agricultural Sciences in China, 9(5), 633-641. https://doi.org/10.1016/S1671-2927(09)60138-3

Wassmann, R., Jagadish, S. V. K., Sumfleth, K., Pathak, H., Howell, G., Ismail, A., ... Heuer, S. (2009). Regional vulnerability of climate change impacts on Asian rice production and scope for adaptation. Advances in Agronomy, 102, 91-133. https://doi.org/10.1016/S0065-2113(09)01003-7

Yang, J, Zhang, J., Wang, Z., Zhu, Q., \& Wang, W. (2001). Remobilization of carbon reserves in response to water deficit during grain filling of rice. Field Crops Research, 71(1), 47-55. https://doi.org/10.1016/ S0378-4290(01)00147-2

Yoshida, S. (1978). Tropical climate and its influence on rice [periodicity, productivity and stability]. IRRI Res. Paper Series 20. IRRI, Los Baños, Philippines.

\section{Copyrights}

Copyright for this article is retained by the author(s), with first publication rights granted to the journal.

This is an open-access article distributed under the terms and conditions of the Creative Commons Attribution license (http://creativecommons.org/licenses/by/4.0/). 